\title{
Pembelajaran Daring dan Luring pada Masa Pandemi Covid-19
}

\author{
Rio Erwan Pratama ${ }^{*}$, Sri Mulyati $2^{*}$, Iwan Susanto ${ }^{3^{*}}$ \\ 1SMA Negeri 1 Belitang, ${ }^{2}$ Dinas Pendidikan Kabupaten Ogan Komering Ulu, ${ }^{3} \mathrm{SD}$ \\ Negeri Sepatnunggal 02 \\ rioerwanpratama@gmail.com
}

\section{Article History}

received 3/12/2020

revised $17 / 12 / 2020$

accepted 31/12/2020

\begin{abstract}
This study aims to explore whether online learning and offline learning can work well, so that educational goals can be achieved. This research is a phenomenological qualitative research to find out how the application of online learning and offline learning in one of the SD Negeri Sepatnunggal 02 in Cilacap Regency, Central Java, Indonesia. The steps of this research include action planning, action implementation, observation stage, and reflection stage. From the results of the study, there were several obstacles in its implementation, but they could be solved well by the teacher in order to educate the students. Both online and offline learning systems are expected for teachers to be creative in educating students, so that learning success can be achieved properly or effectively. This study provides information that teachers actually prefer offline learning where they can interact with students, and also students prefer offline learning with face-to-face interactions.
\end{abstract}

Keywords: online learning, offline learning, Covid-19 pandemic period

\begin{abstract}
Abstrak
Penelitian ini bertujuan untuk mengeksplorasi pembelajaran daring dan pembelajaran luring dapat berjalan dengan baik, agar tujuan pendidikan bisa tercapai. Penelitian ini merupakan penelitian kualitatif fenomenologi untuk mencari tahu bagaimana penerapan pembelajaran daring dan pembelajaran luring di salah satu SD Negeri Sepatnunggal 02 di Kabupaten Cilacap, Jawa Tengah, Indonesia. Langkah-langkah penelitian ini meliputi perencanaan tindakan, pelaksanaan tindakan, tahap pengamatan, dan tahap refleksi. Dari hasil penelitian terdapat ada beberapa kendala dalam pelaksanaannya akan tetapi bisa diselesaikan dengan baik oleh guru demi mencerdaskan perserta didik. Baik sistem pembelajaran daring dan luring diharapkan guru dapat kreatif dalam mendidik peserta didik, supaya keberhasilan pembelajaran bisa tercapai dengan baik atau efektif. Penelitian ini memberikan informasi bahwa guru sebenarnya lebih memilih pembelajaran luring di mana bisa berinteraksi dengan siswa, dan juga siswa lebih menyukai pembelajaran luring dengan adanya tatap muka.
\end{abstract}

Kata kunci: pembelajaran daring, pembelajaran luring, masa pandemi Covid-19

Social, Humanities, and Education Studies (SHEs): Conference Series https://jurnal.uns.ac.id/shes

p-ISSN 2620-9284

e-ISSN 2620-9292 


\section{PENDAHULUAN}

Pendidikan merupakan usaha sadar dan terencana untuk memberikan bimbingan dan pertolongan dalam mengembangkan potensi anak baik jasmani ataupun rohani yang dimana di berikan oleh orang dewasa kepada anak untuk mencapai kedewasaannya serta mencapai tujuan anak menjadi manusia yang beriman, berakhlak mulia, berilmu, kreatif dan mandiri yang dapat di terima di dalam masyarakat. Pendidikan akan memberikan pengalaman-pengalaman belajar di dalam program-program pendidikan formal, nonformal atau informal di sekolah. Sesuai yang diamanatkan dalam Undang-undang Sistem Pendidikan Nasional No. 20 Tahun 2003 pasal 3 menyatakan bahwa tujuan pendidikan nasional adalah untuk mengembangkan potensi peserta didik agar menjadi manusia yang beriman dan bertakwa kepada Tuhan Yang Maha Esa, berakhlak mulia sehat, berilmu, cakap, kreatif, mandiri dan menjadi warga negara yang demokratis serta bertanggung jawab (Republik Indonesia, 2003; Mukartik dkk, 2020; Abdullah, 2020; Apriani dkk, 2020; Amalia, 2019).

Sekolah merupakan institusi yang di harapkan dapat membenntuk karakter generasi muda. Dalam kontek ini pendidikan dimaknai sebagai proses untuk memanusiakan manusia untuk menajadi manusia dewasa seutuhnya. Melalui pendidikan di semaikan pola pikir, nilai- nilai, dan norma-norma di masyarakat (Rohma dkk, 2020; Zulaiha dkk, 2020; Hartiwi dkk, 2020).

Akan tetapi dunia di kejutkan dengan mewabahnya suatu penyakit yang di sebabkan oleh sebuah virus yang bernama corona atau dikenal dengan covid-19 (Corona Virus diseases-19). Yang mulai mewabah 31 Desember 2019 di Kota Wuhan Propinsi Hubei Tiongkok, dan penyebaran virus tersebut saat ini ke seluruh dunia dengan sangat cepat, sehingga WHO tanggal 11 Maret 2020 menetapkan sebagai wabah pademi global. Ratusan ribu manusia terpapar virus ini di seluruh dunia, bahkan menjebabkan puluhan ribu orang meningggal dunia. Tercatat beberapa negara yang menjadi kasus tertinggi terpapar covid-19 yaitu Italia, Amerika Serikat, Tiongkok, Spanyol, dan Iran. Bahkan juga Indonesia terkena dampaknya.

Penularan lewat kontak social antara manusia sulit di prediksi dan juga tidak bisa di hindari sehingga penyebarannya juga sangat pesat. Obat penawar juga belum bisa ditemukan menjadi penyebab banyaknya kematian. Rumitnya penanganan wabah ini membuat para pemimpin dunia dan termasuk Indonesia membuat kebijakan super ketat untuk memutus mata rantai penyebaran covid-19 yaitu dengan menerapkan social distanding (pembatasan interaksi social). Social distancing sendiri berarti tindakan dengan memberi jarak atau menghindari keramaian atau menghindari kontak dalam jarak dekat dengan orang lain. Atau dijelaskan oleh Center for Disease Control (CDC), social distancing merupakan tindakan menjauhi perkumpulan orang dalam jumlah besar, menghindari pertemuan massal dan menjaga jarak antar manusia.

Dengan penerepan social distanding (pembatasan interaksi social) berdampak juga dalam dunia pendidikan. Pemerintah membuat keputusan untuk meliburkan atau memindahkan proses pemebelajaran yang tadinya di sekolah menjadi di rumah. Peralihan pembelajaran ini mamaksa berbagai pihak untuk mengikuti alur yang sekiranya bisa ditempuh agar pembelajaran dapat berlangsung dengan cara memanfaatkan teknologi sebagai media pembelajaran daring. Penggunaan teknologi ini juga sebenarnya terdapat beberapa masalah seperti penguasaan teknologi yang masih rendah, keterbatasan sarana dan prasarana, jaringan internet, biaya, dan motivasi guru serta siswa yang menurun karena bosan menggunakan teknologi tersebut (Komalasari dkk, 2020; Fitria dan Suminah, 2020; Hamzah dkk, 2020; Rohma dkk, 2020).

??Istilah pembelajaran daring dan luring di perkenalkan di era teknologi informasi pada saat ini, pembelajaran daring merupakan singkatan dari pembelajaran dalam jaringan, atau pengganti istilah pembelajaran online yang sering kita gunakan dalam teknologi internet (Ivanova dkk, 2020; Kristiawan dan Muhaimin, 2019; Kristiawan, 
2014). Menurut Ivanova dkk (2020) pembelajaran daring artinya adalah pembelajaran yang dilakukan secara online, menggunakan aplikasi pembelajaran maupun jejaring sosial. Pembelajaran daring merupakan pembelajaran yang dilakukan tanpa melakukan tatap muka, tetapi melalui platform yang telah tersedia. Segala bentuk materi pelajaran didistribusikan secara online, komunikasi juga dilakukan secara online, dan tes juga dilaksanakan secara online. Sistem pembelajaran melalui daring ini dibantu dengan beberapa aplikasi, seperti Google Classroom, Google Meet, Edmudo dan Zoom. Sedangkan menurut Hamid Muhammad sebagai plt. Dikdasmen Kemendikbud pembelajaran daring adalah pembelajaran yang menggunakan model interaktif berbasis internet dan Learning Manajemen System (LMS). "Pembelajaran daring ini dilakukan selama ini secara interaktif seperti Zoom, Google Meet. Itu salah satu (pembelajaran) yang kami sarankan agar ada interaksi antar guru dan murid di mana (catatannya) tak ada hambatan di gawai, internet, dan pulsa. Sedangkan pembelajaran luring merupakan singkatan dari pembelajaran di luar jaringan atau dengan istilah offline, artinya pembelajaran ini tidak lain merupakan pembelajaran konvesional yang sering digunakan oleh guru sebelum adanya pandemic covid 19 akan tetapi ada perubahan tertentu seperti jam belajarnya lebih singkat dan materinya sedikit (https://www.kompas.com/edu/read/2020/06/16/200131471/pembelajaranjarak-jauh-bukan-pembelajaran-daring-ini-penjelasannya) .Pembelajaran dengan??metode Luring atau offline merupakan pembelajaran yang dilakukan di luar tatap muka oleh guru dan peserta didik, namun dilakukan secara offline yang berarti guru memberikan materi berupa tugas??hardcopy kepada peserta didik kemudian dilaksanakan di luar ?? sekolah (https://www.kemdikbud.go.id/main/blog/2020/05/kemendikbud-terbitkan-pedomanpenyelenggaraan-belajar-dari-rumah)

Di masa pandemi covid 19 banyak cara dilakukan pihak sekolah untuk pembelajaran tetap berlangsung seperti menerapkan pembelajaran daring dan pembelajaran luring. Walaupun terkadang tujuan pembelajaran yang ingin di sampaikan belum tercapai dengan baik, akan tetapi di harapkan dari proses tersebut di harapkan perserta didik mampu menerima pembelajaran baik pembelajaran daring ataupun pembelajaran luring. Termasuk upaya yang di lakukan sekolah untuk mencerdaskan peserta didiknya (Zulaiha dkk, 2020; Soleh dkk, 2019; Septiani dan Cahyono, 2019; Nugraha, 2019; Listiningrum dkk, 2020).

\section{METODE}

Dalam penelitian ini menggunakan penelitian kualitatif dengan jenis metode fenomenologi, yang di mana penelitian ini tujuannya untuk melihat fenomena yang terjadi dalam kehidupan di masyarakat, metode fenomenologi menggali data untuk menentukan fenomena esensial seperti pengamalaman dari seorang peneliti. Tujuan penelitian ini adalah untuk mencari tahu bagaimana penerapan pembelajaran daring dan pembelajaran luring di salah salah satu SD Negeri Sepatnunggal $02 \mathrm{Kec}$. Majenang Kab. Cilacap, Jawa Tengah. Menurut (Sugiyono, 2017) yang di maksud dengan metode penelitian adalah metode penelitian pada dasarnya merupakan cara ilmiah untuk mendapatkan data dengan tujuan dan kegunaan tertentu. Jadi metode penelitian adalah merupakan suatu cara mencari, memperoleh, menyimpulkan, atau mencatat data, baik primer ataupun skunder yang dimana digunakan untuk keperluan menyusun karya ilmiah. Dalam penelitian ini menggunakan sample guru-guru di salah satu SD Negeri Sepatnunggal 02 Kec. Majenang Kab. Cilacap, Jawa Tengah yang berjumlah 8 orang. Langkah- langkah penelitian ini meliputi perencanaan tindakan, pelaksanaan tindakan, tahap pengamatan, dan tahap refleksi.

Perencanaan tindakan

Pada tahap ini, peneliti menjelaskan tentang apa (what), mengapa (why), dimana (where), kapan (when), dan bagaimana (how) penelitian dilakukan. Penelitian tindakan 
kelas sebaiknya dilakukan secara kolaboratif, sehingga menghindarkan unsur subjektivitas. Di dalam penelitian, ada kegiatan pengamatan terhadap diri sendiri, yaitu pada saat peneliti menerapkan pendekatan, model, atau metode pembelajaran sebagai upaya menyelesaikan masalah pada saat praktik penelitian. Dibutuhkan rekan sejawat untuk menilai kegiatan tersebut. Di dalam tahap perencanaan, peneliti juga perlu menjelaskan persiapan-persiapan pelaksanaan penelitian, seperti rencana pelaksanaan pembelajaran dan instrumen pengamatan (observasi). Dalam perencanaan tindakan di masa covid 19 ini guru diberi pilihan menggunakan satuan pendidikan dalam kondisi khusus sesuai dengan pedoman pelaksanaan kurikulum pada satuan pendidikan sesuai intruksi dari Kementerian Pendidikan dan Kebudayaan seperti 1) tetap menggunakan kurikulum nasional, 2) menggunakan kurikulum darurat, 3) membuat atau menyederhanakan kurikulum sendiri. Dalam penelitian ini peneliti menggunakan kurikulum darurat yang mengacu dengan ketentuan dari Kemendikbud.

Pelaksanaan tindakan (Acting)

Pada tahap pelaksanaan, dilakukan kegiatan implementasi atau penerapan perencanaan tindakan. Di dalam kegiatan implementasi ini, maka guru (peneliti) harus mentaati perencanaan yang telah disusun. Hal yang perlu diperhatikan pada tahap ini adalah pembelajaran harus berjalan seperti biasanya, tidak boleh kaku dan terkesan dibuat-buat. Kolaborator disarankan untuk melakukan pengamatan secara objektif sesuai kondisi pembelajaran yang dilakukan peneliti. Kegiatan ini penting karena tujuan penelitian tindakan kelas adalah untuk memperbaiki proses pembelajaran.

Tahap pengamatan

Pada tahap pengamatan terdapat dua kegiatan yang akan diamati, yaitu kegiatan belajar peserta didk dan kegiatan pembelajaran. Pengamatan terhadap proses belajar peserta didik dapat dilakukan sendiri oleh guru pelaksana (peneliti) sambil melaksanakan pembelajaran, Sedangkan pengamatan terhadap proses pembelajaran, guru pelaksana (peneliti) dapat meminta bantuan kepada teman sejawat yang bertindak sebagai kolaborator untuk melakukan pengamatan. Kolaborator melakukan pengamatan pembelajaran berdasarkan instrumen yang telah disusun oleh peneliti. Hasil pengamatan dari kolaborator nantinya akan bermanfaat atau akan digunakan peneliti sebagai bahan refleksi untuk perbaikan pembelajaran berikutnya. Pembelajaran di masa pandemi Covid-19 ini, guru sebenarnya lebih memilih pembelajaran luring di mana bisa berinteraksi dengan siswa, dan juga siswa lebih menyukai pembelajaran luring dengan adanya tatap muka.

Refleksi

Kegiatan refleksi dilaksanakan ketika kolaborator sudah selesai melakukan pengamatan terhadap peneliti dalam melaksanakan pembelajaran. Kegiatan ini dapat berupa diskusi hasil pengamatan yang dilakukan oleh kolaborator dengan guru pelaksana (peneliti). Tahap ini merupakan inti dari penelitian tindakan kelas, yaitu ketika kolaborator mengungkapkan hal-hal yang dirasakan sudah berjalan baik dan bagian yang belum berjalan dengan baik pada saat peneliti mengelola proses pembelajaran. Hasil refleksi dapat digunakan sebagai bahan pertimbangan dalam merancang siklus berikutnya. Sehingga pada intinya, refleksi merupakan kegiatan evaluasi, analisis, pemaknaan, penjelasan, penyimpulan, dan identifikasi tindak lanjut dalam perencanaan siklus berikutnya.

Teknik pengumpulan data dalam penelitian ini menggunakan teknik wawancara untuk memperoleh data tentang kesulitan guru dalam pembelajaran daring ataupun luring, observasi untuk mengamati implementasi pembelajaran daring dan pembelajaran luring tersebut di laksanakan untuk memperoleh data keberhasilan dari implementasi pembelajaran daring dan pembelajaran luring. Indikator keberhasilan penelitian ini adalah siswa mendapatkan nilai kriteria baik. Objek penelitian ini adalah guru-guru di salah satu SD Negeri Sepatnunggal 02 Kec. Majenang Kab. Cilacap, 
Jawa Tengah, Indonesia yang berjumlah 8 orang. Sedangkan waktu pelaksanaan selama 6 hari di mulai dari tanggal 12 Oktober 2020 sampai 24 Oktober 2020.

\section{HASIL DAN PEMBAHASAN}

Penelitian ini diadakan di salah satu SD Negeri Sepatnunggal $02 \mathrm{Kec}$. Majenang Kab. Cilacap, Jawa Tengah, sekolah tersebut telah mengadakan pembelajaran daring dan pembelajaran luring di semester ganjil tahun pelajaran 2020/2021 ini, sebelumnya sekolah ini telah mengadakan pembelajaran daring di semester genap tahun pelajaran 2019/2020.

Langkah-langkah tugas pelaksanaan daring yaitu tugas kepala sekolah 1) Kepala sekolah memberikan surat tugas kepada guru untuk melakukan kegiatan pembelajaran di rumah sesuai dengan kelas atau mata pelajaran yang diampu guru melalui berbagai media online; 2) membuat surat edaran kepada orangtua tentang pelaksanaan pembelajaran di rumah atau home learning dalam rangka meningkatkan kewaspadaan dan pencegahan penularan virus corona di sekolah;

3) melakukan sosialisasi kepada siswa mengenai media pembelajaran secara daring dan tata cara penggunaan media tersebut; 4) melakukan pengendalian dan pengawasan atas pelaksanaan pembelajaran di rumah yang telah ditugaskan kepada guru; 5) melaporkan hasil kegiatan belajar di rumah kepada dinas pendidikan (kompas.com, 2020).

Tugas guru antara lain 1) menyiapkan bahan ajar yang akan diunggah atau disebarkan kepada siswa melalui media atau aplikasi pembelajaran yang dipilih; 2) guru menentukan media belajar yang sesuai dengan kondisi siswa agar belajar di rumah dapat berjalan secara efektif. Beberapa media yang dapat dipilih antara lain; grup Whatsapp, email, Google Clasroom, atau aplikasi media belajar lain rekomendasi Kemendikbud; 3) guru mengunggah media pembelajaran berupa modul, tutorial, video, latihan soal, lembar kerja siswa ke media yang telah ditetapkan atau disepakati bersama; 4) guru wajib memberikan penjelasan atas pertanyaan yang disampaikan siswa; dan 5) guru memeriksa dan melakukan evaluasi atas proses pembelajaran daring atau belajar di rumah ini untuk mendapatkan umpan balik hasil pembelajaran.

Tugas siswa yaitu mempelajari bahan atau materi mata pelajaran diunggah guru melalui media yang telah disepakati. Siswa dapat melakukan diskusi dengan guru melalui media online jika masih ada hal yang kurang jelas dari materi yang diberikan.

Tugas orangtua 1) memastikan siswa melaksanakan kegiatan belajar di rumah masing- masing dan membatasi izin kegiatan di luar rumah; 2) melakukan koordinasi dengan wali kelas, guru atau sekolah; dan 3) membantu siswa menerapka pola hidup bersih sehat (PHBS) di rumah. Sedangkan langkah-langkah yang harus disiapkan pembelajaran luring yaitu Pra pembelajaran 1) menyiapkan RPP; 2) menyiapkan bahan ajar, jadwal dan penugasan kemudian mengirimkannya ke peserta didik/orang tua/wali; 3) memastikan semua siswa telah mendapatkan lembar jadwal dan penugasan; 4) guru dan orang tua/wali siswa bertemu untuk menyerahkan jadwal dan penugasan diwajibkan melakukan prosedur keselamatan pencegahan Covid-19; 5) jadwal pembelajaran dan penugasan belajar diambil oleh orang tua/wali siswa sekali seminggu di akhir minggu dan atau disebarkan melalui media komunikasi yang tersedia. Saat pembelajaran, 1) pembelajaran luring dibantu orang tua/wali siswa sesuai dengan jadwal dan penugasan yang telah diberikan; 2) guru dapat melakukan kunjungan ke rumah siswa untuk melakukan pengecekan dan pendampingan belajar. Jika ini dilaksanakan, wajib melakukan prosedur pencegahan penyebaran Covid-19; dan 3) berdoa bersama sebelum dan sesudah belajar.

Usai pembelajaran 1) setiap siswa mengisi lembar aktivitas sebagai bahan pemantauan belajar harian; 2) orang tua/wali siswa memberikan tandatangan pada tiap sesi belajar yang telah tuntas di lembar pemantauan harian; 3) penugasan diberikan 
sesuai dengan jadwal; 4) hasil penugasan berikut lembar pemantauan aktivitas harian dikumpulkan setiap minggu sekaligus mengambil jadwal dan penugasan untuk minggu berikutnya. Ini dapat juga dikirim melalui alat komunikasi; dan 4) muatan penugasan adalah pendidikan kecakapan hidup, antara lain mengenai pandemi Covid-19. Selain itu perlu dipastikan adanya konten rekreasional dan ajakan melakukan olahraga/kegiatan fisik dalam upaya menjaga kesehatan mental dan fisik siswa.

Sistem pembelajaran daring dan luring mau tidak mau harus dilakukan di tengah wabah covid-19. Sebab, tidak mungkin peserta didik dibiarkan saja libur panjang hingga menggunggu covid 19 akan hilang. Dalam pembelajaran daring dan luring di sekolah ini pada masa pandemi covid-19 terdapat beberapa kendala seperti terbatasnya waktu pembelajar karena waktu pembelajaran di kurangi sehingga materi yang di sampaikan tidak tuntas. Untuk pembelajaran luring kelemahannya yaitu terkendala internet yang lemot dan kuota internet yang terbatas (Risdianto dkk, 2020).

Dalam pembelajaran di masa pandemi Covid 19 ini di sekolah ini menggunakan berbagai cara supaya pembelajaran tetap berjalan seperti menggunakan pembelajaran daring terlebih dahulu dengan menggunakan media social seperti aplikasi WhatsApp, Google Classrom, Google Meet, Edmodo dan Zoom. Supaya dalam peroses pembelajaran bisa berjalan lancar guru harus memandu pembelajaran terlebih dahulu, dalam pembelajaran daring sebenarnya siswa lebih menyukai karena pembelajaran lebih menarik, membuat siswa menjadi penasaran dalam prosesnya membuat siswa menjadi aktif. Akan tetapi terkadang menemukan kendala seperti terdapatnya siswa yang tidak mengerjakan tugas dengan alasan tidak memiliki fasilitas teknologi yang mendukung seperti smartphone di karenakan orang tua dari siswa tersebut tidak mampu membelikan atau di rumahnya hanya ada satu saja sehingga bergantian dengan keluarganya yang lain, tidak adanya sinyal di tempat mereka tinggal, dan tidak adanya pulsa yang memadai. Di karenakan kendala tersebut maka sekolah ini mencoba menggunakan pembelajaran luring dengan tatap muka akan tetapi siswa dibatasi untuk hadir yaitu separuhnya dari satu kelas yang berjumlah 18 siswa jadi hanya 9 siswa yang hadir yang di bagi berdasarkan ganjil dan genap menurut absen. Dalam proses pembelajaran ini waktu pembelajaran juga dibatasi satu jam pelajaran hanya 23 menit atau 30 menit, akan tetapi sekolah juga tidak memaksakan siswanya untuk memilih pembelajaran luring karena ada beberapa siswa yang masih melakukan pembelajaran daring, jadi presentasi dari yang melakukan pembelajaran kurang lebih sejumlah $98 \%$.

Jadi dilihat berdasarkan berdasarkan proses pembelajaran daring atau luring yang dilaksanakan di sekolah ini peran guru tidak bisa digantikan dengan apapun. Untuk itu semoga tidak ada lagi guru yang di kriminalisasikan lagi dalam upaya mendisiplinkan siswa, karena berkat gurulah bangsa kita ini mendapatkan generasi yang sesuai diamanatkan UU Sisdiknas. Semoga nantinya pandemi Covid-19 ini segera berakhir agar pembelajaran bisa di laksanakan seperti biasanya.

\section{SIMPULAN}

Sejak kasus covid-19 mulai meningkat, sekolah atau universitas tidak lagi melakukan aktivitas seperti biasa, karena pemerintah memberlakukan sistem di rumah saja, salah satu langkah yang tepat untuk mengatasi masalah ini adalah menggunakan teknologi jaringan dan informasi bagi system pembelajaran terutama di sekolah, dalam perosesnya banyak sekali kendala-kendala yang di adapi oleh guru yang di mana pembelajaran daring ini baru pertama kali dilakukan seperti terkendala dengan sinyal dan lain-lain, akan tetapi kendala tersebut bukan menjadi penghalang untuk mendidik peserta didik, seiring berjalannya waktu pemerintah mengizinkan pihak sekolah untuk membuka kembali pembelajaran di sekolah maka terciptalah pembelajaran luring. Setiap pembejalan terkadang adanya kelebihan dan kekurangan termasuk pembelajaran daring dan luring di masa pandemi Covid-19 ini, akan tetapi dari sistem 
pembelajaran daring dan luring diharapkan guru untuk kreatif dalam mendidik peserta didik. Supaya keberhasilan pembelajaran bisa tercapai dengan baik atau efektif.

\section{DAFTAR PUSTAKA}

Abdullah, A. (2020). Relationship the Work Culture and Training Programs Within Performance. International Journal of Progressive Sciences and Technologies (IJPSAT), 20(1).

Amalia, D. (2019). Promoting Just Culture For Enhancing Safety Culture In Aerodrome Airside Operation. International Journal of Scientific \& Technology Research 8 (10)

Apriani, N., Fatonah, F., \& Oka, I. A. M. (2020). Rancangan Sistem Pengolahan Sertifikat Berbasis Website Sebagai Upaya Untuk Peningkatan Evaluasi Kompetensi Safety Personil Di Lingkungan PT Angkasa Pura II (Persero). Langit Biru: Jurnal IImiah Aviasi, 17-28.

Community Participation on the Quality of Educational Services. Journal of Social Work and Science Education, 1(1), 45-57.

Fitria, H., \& Suminah, S. (2020). Role of Teachers in Digital Instructional Era. Journal of Social Work and Science Education, 1(1), 70-77.

Hamzah, S., Yussof, M. H. B., \& Enriquez, A. A. (2020). Togetherness in the Diversity of the Pancasila Ideology Frame. Journal of Social Work and Science Education, $1(1), 8-12$.

Ivanova, T., Gubanova, N., Shakirova, I., \& Masitoh, F. (2020). Educational technology as one of the terms for enhancing public speaking skills. Universidad y Sociedad, 12(2), 154- 159.

Komalasari, K., Arafat, Y., \& Mulyadi, M. (2020). Principal's Management Competencies in Improving the Quality of Education. Journal of Social Work and Science Education, 1(2), 181-193

Kristiawan, M. (2014). A Model for Upgrading Teachers Competence on Operating Computer as Assistant of Instruction. Global Journal of Human-Social Science Research.

Kristiawan, M., \& Muhaimin, M. (2019). Teachers' Obstacles In Utilizing Information and Communication Technology. International Journal of Educational Review, $1(2), 56-61$.

Listiningrum, H. D., Wisetsri, W., \& Boussanlegue, T. C. H. A. B. L. E. (2020). Principal's Entrepreneurship Competence in Improving Teacher's Entrepreneurial Skill in High Schools. Journal of Social Work and Science Education, 1(1), 87-95.

Murkatik, K., Harapan, E., \& Wardiah, D. (2020). The Influence of Professional and Pedagogic Competence on Teacher's Performance. Journal of Social Work and Science Education, 1(1), 58-69

Nugraha, W. (2019) Safety Documentation: A Communication Approach For Safety Management System In Aerodrome Operator. International Journal of Scientific \& Technology Research 8 (11), 1705-1711

Risdianto, E., Fitria, J., Johan, H., \& Macariola, J. S. (2020). Teacher's Perception of Thermodynamic Law Module Developed in Training through Student's Critical Thinking Skills. Journal of Social Work and Science Education, 1(1), 78-86.

Rohma, S., Harapan, E., \& Wardiah, D. (2020). The Influence of School-Based Management and Teacher's Professionalism toward Teacher's Performance. Journal of Social Work and Science Education, 1(1), 13-23.

Republik Indonesia. (2013). Undang-Undang Sistem Pendidikan Nasional No 20 tahun 2003.

Septiani, V., \& Cahyono, D. (2019). Education and Training Strategy in Palembang Aviation College. International Journal of Recent Technology and Engineering, 8 (3) 
Soleh, A. M., Tobari., Kesumawati, N. (2019). Development of The Practical Manual As A Learning Media For Simulator Aircraft Rescue And Fire Fighting. International Journal of Scientific \& Technology Research 8(10).

Sekretariat Negara. Jakarta

Sugiyono. (2017). Metode Penelitian Kuantitatif, Kualitatif, dan R\&D. Bandung: Alfabeta. Zulaiha, D., Lian, B., \& Mulyadi, M. (2020). The Effect of Principal's Competence and

https://www.kemdikbud.go.id/main/blog/2020/05/kemendikbud-terbitkan-pedomanpenyelenggaraan-belajar-dari-rumah.

https://www.kompas.com/edu/read/2020/06/16/200131471/pembelajaran-jarak-jauhbukan- pembelajaran-daring-ini-penjelasannya 